\title{
Analisa Faktor-Faktor Pengaruh Minat Beli Paket Data Telkomsel dengan Masa Pandemi Covid 19 Sebagai Variabel Moderating
}

\author{
Astri Mariana Isniawati ${ }^{1}$ dan Muhammad Jalari² \\ Sekolah Tinggi Ilmu Ekonomi Surakarta \\ Jl. Slamet Riyadi No. 435-437, Dusun I, Makamhaji Kec. Kartasura, Sukoharjo \\ Email: astrimarianaa@gmail.com
}

\begin{abstract}
The purpose of this study is to find out what factors influence the interest in buying telkomsel data packages with the covid 19 pandemic as a moderation variable. The type of population in this study is an unlimited population. Data collection techniques use non probability techniques on purposive sampling types. Data collection was conducted by the method of disseminating questionnaires and samples of 70 respondents. The data analysis technique used is multiple linear regression analysis using SPSS version 19. The result of this study is that the quality of the product does not have a significant effect on the purchase interest of telkomsel data package, the brand image has a significant effect on the purchase interest of telkomsel data package, the advertisement does not have a significant effect on the purchase interest of telkomsel data package, during the covid 19 pandemic it has a significant effect on the buying interest of telkomsel data package.
\end{abstract}

Keywords: Product Quality, Brand Image, Price, Advertising, During the Covid 19 Pandemic, Interest in Buying Telkomsel Data Package

\begin{abstract}
Abstrak- Penelitian ini mempunyai tujuan yaitu guna melihat faktor apa saja yang memberi pengaruh pada minat beli paket data telkomsel dengan di masa pandemi covid 19 sebagai variabel moderasinya. Jenis populasi pada penelitian ini yaitu populasi tidak terbatas. Teknik pengumpulan data menggunakan teknik non probability pada jenis purposive sampling. Metode penyebaran kuesioner dan sampel 70 respondeng dilakukan untuk mengumpulkan data. Teknik analisis data yang dipergunakan yaitu analisis regresi linier berganda dengan memakai SPSS versi 19. Penelitian ini memperlihatkan kualitas produk tidak mempunyai pengaruh yang signifikan pada minat beli paket data telkomsel, iklan tidak memberi pengaruh signifikan terhadap minat beli paket data telkomsel, price memberi pengaruh positif pada minat beli paket data telkomsel, citra merek memberi pengaruh yang positif terhadap minat beli paket data telkomsel, di masa pandemi covid 19 membawa pengaruh signifikan terhadap minat beli paket data telkomsel.
\end{abstract}

Kata Kunci: Kualitas Produk, Brand Image, Price, Iklan, Di Masa Pandemi Covid 19, Minat Beli Paket Data Telkomsel

\section{PENDAHULUAN}

Isu pada penelitian ini adalah adanya kenaikan penjualan paket data Telkomsel selama masa pandemi Covid 19 ini dimana hal itu menyebabkan meningkatnya minta beli konsumen terhadap paket data Telkomsel. Di masa pandemi saat ini paket data adalah suatu kebutuhan yang penting untuk mendukung kegiatan sehari-hari. Hal ini disebabkan oleh berubahnya pola kehidupan saat pandemi ini, dimana semua kegiatan mulai dari bekerja dan bersekolah dilakukan secara daring dirumah guna mengurangi penyebaran Covid 19[1].

Permasalahan yang mendasari penelitian ini adalah perubahan pola hidup selama masa pendemi Covid 19 di Indonesia, dimana seluruh kegiatan berubah menjadi daring yang menyebabkan meningkatnya minat beli paket data pada masyarakat. Minat beli merupakan tahapan yang diambil konsumen dalam memperoleh keputusan sebelum kegiatan membeli akan dilaksanakan[2]-[4]. Menurut kotler dan Armstrong,[5] Kualiats produk yaitu potensi suatu produk untuk menampilkan kegunaan dari produk tersebut yang berupa reliabilitas, durabilitas, ketepatan, kemudahan reparasi dan pengoperasian produk serta kelengkapan produk yang lain. Sedangkan brand image yaitu pendapat pembeli pada sebuah produk berdasarkan kepuasan yang mereka dapatkan [6], [7]. Selain itu, harga merupakan semua bentuk biaya moneter yang dikeluarkan oleh pembeli guna mendapatkan, mempunyai, menggunakan manfaat dari kombinasi antara barang dan layanan suatu produk[1], [8] sedangkan iklan adalah agen penyampaian suatu pesan gaya hidup dan bagian dari gaya hidup itu sendiri[9].

Perusahaan telekomunikasi di Indonesia berlomba-lomba untuk memenuhi kebutuhan para pembelinya serta terus melakukan usaha guna menguasai pangsa pasar yang ada, hal ini karena melihat fenomena meningkatnya penggunaan paket data internet selama masa pandemi covid-19 saat ini. Terdapat beberapa perusahaan telekomunikasi di Indonesia, antara lain Telkomsel, Indosat, XL, Three, Smartfren, dan lain sebagainya. Telkomsel merupakan perusahaan telekomunikasi terbesar di Indonesia, tetapi ada juga beberapa pesaing yang lain yang ingin mengalahkan kekuasaan telkomsel sebagai perusahaan 
telekomunikasi terbesar di Indonesia. Persaingan tersebut sangat kuat, dimana sejumlah beberapa perusahaan telekomunikasi berusaha untuk mendapatkan minat beli konsumen dengan mengeluarkan paket data dengan harga yang terjangkau[10]-[12].

Dari pernyataan yang telah disampaikan di atas, penelitian memiliki gagasan bahwa minat beli paket data telkomsel pada masa pandemi ini sangat meningkat. Konsumen memilih paket data yang sesuai dengan kebutuhannya dimasa pandemi saat ini, tak lupa juga untuk memperhatikan kualitas produk yang akan dibeli, apakah sesuai dengan kebutuhannya atau tidak. Konsumen akan memilih paket data dengan harga yang terjangkau serta sesuai dengan kebutuhannya, merek yang ternama akan mendorong pembeli supaya produk dari perusahaan telekomunikasi itu.

\section{Kualitas Produk}

\section{KAJIAN PUSTAKA}

Kualitas produk merupakan keadaan, bentuk dan kegunaan sebuah produk baik jasa maupun yang telah disesuaikan dengan tingkat mutu supaya bisa memenuhi kebutuhan serta kepuasan konsumen. Kotler dan Keller menerangkan bahwa potensi sebuah barang dalam memberi hasil maupun keinerja yang cocok bahkan bisa lebihh dari yang diharapkan pembeli[5].

Petr.S, Jiri.R dan Maria.K telah melakukan penelitian yang berjudul "Customer Satisfaction, Product Quality and Performance of Companies" menjelaskan bahwa mutu sebuah produk adalah potensi sebuah produk dalam memenuhi keinginan dai konsumen yang bisa membuat rasa puas konsumen tersebut bisa dicapai[13].

Berdasarkan kajian terdahulu dapat disimpulkan bahwa kualitas produk berkaitan erat dengan kepuasaan konsumen dimana dapat dikatakan produk itu baik jika produk tersebut dapat memenuni keinginan dan kepuasaan konsumennya. Tetapi di era moderen ini kualitas produk memang sangat diperhatikan walaupun pasti memiliki kekurangan di setiap modelnya.

\section{Brand Image}

Brand Image yaitu gambaran dari keseluruhan presepsi terhadap merek berdasarkan pesan serta history masa lalu merek tersebut. Kotler menerangkan bahwa komentar pembeli dari sebuah merek yang didasari buruk atau baiknya merek tersebut yang diingat pembeli[5], [14], [15].
Selain itu brand image sejumlah presepsi konsumen terkait merek yang didapatkan dari interaksi afektif, kognitif atau evaluative di benak konsumen[16].

Mengacu pada pengertian tersebut bisa disimpulkan bahwa brand image yaitu pemikiran atau presepsi pelanggan pada sebuah merek produk baik secara positif maupun negatif yang mempengaruhi pemikiran pelanggan untuk membeli merek itu kembali. Seiring berjalannya waktu banyak bermunculan merek-merek dengan nama yang sama, sehingga kadang pembeli sering bingung dalam menentukan pilihannya untuk membeli suatu produk.

\section{Price (Harga)}

Price yaitu nilai dari suatu produk jasa dan barang agar manfaat yang didapat dari produk tersebut. price merupakan satuan moneter (tidak terkecuali jasa atau barang yang lain) yang ditukarkan supaya mendapatkan hak penggunaan atau kepemilikan dari sebuah jasa atau barang yang memberikan rasa puas untuk pelanggan[8], [17], [18].

Kajin lain mengemukakan bahwa price merupakan total uang yang dikeluarkan dalam memperoleh beberapa kombinasi layanan atau produk[19].

Menurut definisi tersebut bisa disimpulkan harga yaitu lambang dari sebuah produk yang harus konsumen bayar untuk mendapatkan manfaat dari produk tersebut. Pada era sekarang harga suatu produk sangat bervariasi terkadang merek satu dengan merek yang lainnya selisih harga sangatlah tipis sehingga membuat konsumen bingung dalam memilih suatu produk merek tertentu.

Iklan

Iklan yaitu suatu pemberitahuan yang mendorong atau membujuk khalayak supaya memakai jasa dan produk yang ditawarkan. Iklan yaitu suatu cara komunikasi yang dilakukan secara tidak langsung, yang dilandaskan pada sebuah informasi terkait keunggulan, yang ditata sedemikian rupa yang bisa memberi rasa senang, dan akan membuat orang berubah pikiran dalam membeli[9], [20], [21].

G.Shabbir.K.N, Javaria.S, B.Ali.S, A.Imran.H telah melakukan penelitian dengan judul "Effective Advertising And Its Influence On Consumer Buying Behavior" memparkan bahwa iklan adalah bentuk komunikasi agar bisa meyakinkan pendengar dalam memutuskan pembelian suatu layanan atau produk serta memberikan pesan pemirsa[22].

Dari definisi diatas dapat ditarik kesimpulan iklan adalah cara penyampaian promosi terhadap suatu produk atau layanan kepada calon pembeli sehingga 
menimbulkan suatu keyakinan dari calon pembeli untuk membeli produk atau layanan tersebut. Era sekarang iklan dapat dilakukan di berbagai media termasuk media sosial dengan harga yang bervariasi sehingga memudahkan parang pemilik produk untuk mengiklankan produk mereka kepada konsumen.

\section{Minat Beli}

Minat beli merupakan pengakuan mental dari pelanggan yang menunjukkan keinginan untuk membeli sebuah barang dengan merek tertentu dan tahapan dimana pelanggan menentukan pilihan mereka dari banyaknya merek yang digabungkan pada suau pilihan, yang pada akhirnya membeli sebuah barang yang sangat disukai atau proses yang lalui pembeli dalam membli sebuah jasa maupun produk dilandaskan dari berbagai pertimbangan[23], [24].

Harisno dan Herby telah melakukan penelitian yang berjudul "The Analysis Of Factors Affecting The Buying Interest Of E-Commerce Customers" menjelaskan bahwa minat beli yaitu sebesar apa kemungkinan pembeli untuk membeli sebuah produk atau berpindah dari merek tersebut[25].

Dari definisi diatas dapat ditarik kesimpulan minat beli adalah sebuah keyakinan dari pelanggan untuk membeli suatu produk tertentu. Pada era sekarang minat beli pelanggan pada sebuah barang sangatlah tinggi hal tersebut di sebabkan oleh banyak faktor contohnya kualitas produk rang itu sendiri, harga yang di tawarkan oleh suatu brand, diskon yang di berikan.

\section{Dimasa Pandemi Covid 19}

Berdasarkan situs WHO Covid-19 yaitu virus yang bisa menimbulkan sebuah penyakit bagi hewan atau manusia. Virus ini diketahui menimbulkan infeksi pernapasan pada manusia mulai dari flu sampai yang lebih parah seperti MERS dan SARS. Pandemi merupakan wabah penyakit yang ada dengan luas di dunia. Bisa dikatakan, Covid-19 telah menjadi sebuah permasalahan untuk semua orang di dunia[26].

David.M.M, Peter.D, Howard.M, Jeffery.K.T telah melakukan penelitian yang berjudul "Pandemic COVID-19 Joins History's Pandemic Legion" yang menjelaskan bahwa sejak desember 2019, dunia telah menyaksikan kelahiran dalam gerakan lambat dan pertumbuhan pesat penyakit pandemi baru, penyakit coronavirus (CoV) 2019 (COVID-19) [27].

Dari penjelasan diatas dapat disimpulkan bahwa virus yang dapat menyebar dapat menyebabkan adanya siatuasi pendemi yang mempengaruhi hampir seluruh penjuru dunia. Pada era sekarang dimana pandemi covid 19 sedang berlangsung menyebabkan kegoyahan dunia perekonomian karena keterbatasan aktivitas masyarakat demi mengurangi penyebaran virus tersebut.

\section{Kerangka Pikir}

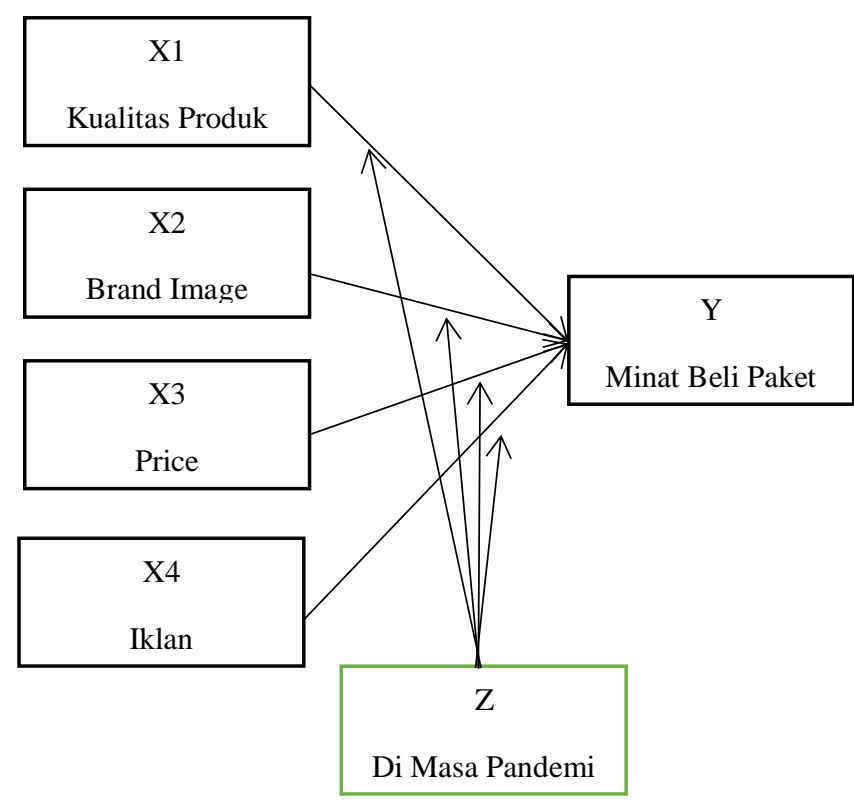

Gambar 1. Kerangka Pikir

\section{Hipotesis}

Hipotesis yaitu jawaban sementara pada sebuah permaslahan yang memiliki sifat dugaan sebab masih harus dicari bukti kebenarannya. Dugaan jawaban tersebut sebagai kebenaran yang memiliki sifat sementara, yang masih diuji kebenarannya melalui data yang terkumpul dari penelitian. hipotesis merupakan jawaban yang sifatnya sedangkan di rumusan masalah penelitian, rumusan masalah tersebut dinyatakan berupa kalimat pernyataan[28].

\section{Pengaruh Kualitas Produk Terhadap Minat Beli}

proses penilaian secara menyeluruh pada konsumen atas perbaikan kinerja suatu barang, itulah yang disebut kualitas produk. kualitas produk berpengaruh baik terhadap minat beli, dimana minat beli yang tinggi bisa dibentuk dengan adanya kualitas produk yang menarik[29], [30].

H1: Diduga Kualitas Produk membawa pengaruh siginifikan pada Minat Beli

\section{Pengaruh Brand Image Terhadap Minat Beli}

Kotler dan keller mengatakan bahwa brand image sebagai presepsi terkait sebuah merek seperti yang direfleksikan oleh asosiasi merek yang ada di benak pelanggan[5]. Sedangkan brand image memberi pengaruh signifikan pada minat beli, maka apabila terdapat peningkatan terhadap brand image, serta akan 
menyebabkan minat beli muncul agar membeli barang itu[31].

H2: Diduga Citra Merek memberi pengaruh signifikan pada Minat Beli

\section{Pengaruh Harga Terhadap Minat Beli}

Price adalah total uang yang dibutuhkna pada sebuha jasa dan produk, atau sejumlah nilai yang ditukar oleh pembeli supaya memperoleh manfaat atau kepemilikan atas suatu jasa atau barang[19]. Sedangkan price memberi pengaruh signifikanpada minat beli, dimana minat beli yang tinggi bisa diperoleh dengan adanya harga yang ditawarkan oleh penyedia barang atau jasa[32].

H3: Diduga Harga membawa pengaruh positif pada Minat Beli

\section{Pengaruh Iklan Terhadap Minat Beli}

Iklan merupakan segala cara penyajian atau promosi ide, produk dan jasa dengan cara non-personal oleh suatu sponsor tertentu yang harus dibayar. Kemudian iklan memberi pengaruh positif pada minat beli dimana iklan yang di ciptakan oleh perusahaan akan menumbuhkan minat beli konsumen[24].

H4: Diduga Iklan berpengaruh signifikan terhadap Minat Beli

\section{Pengaruh Di Masa Pandemi Covid 19} Terhadap Minat Beli

Pandemi Covid-19 merupakan peristiwa menularnya penyakit virus corona di dunia untuk seluruh negara. Sedangkan pandemi Covid 19 memberi pengaruh negatif serta positif pada minat beli hal tersebut membuktikan bahwa terdapat penurunan variabel pandemi virus Covid 19 yang bisa menyebabkan peningkatan minat beli minat beli[33].

H5: Diduga Masa Pandemi Covid 19 mempunyai pengaruh tidak signifikan pada Minat Beli

\section{METODE PENELITIAN}

Pada penelitian ini, peneliti memakai jenis penelitian kuantitatif. Yang dimaksud penelitian kuantitatif yaitu penelitian ilmiah yang sistematis pada beberapa bagian serta gejala dan mutu korelasinya. Menurut Sugiyono [28] penelitian kuantitatif merupakan metode penelitian yang mengacu pada filsafat positivisme, dilakukan guna meneliti pada sampel dan populasi tertentu, teknik pengambilan sampel basanya diambil dengan cara acak, pengumpulan data memakai instrumen penelitian, analisis data yang sifatnya kuantitatif yang tujuannya guna menguji hipotesis yang sudah ditentukan.

Penelitian ini memakai metode Non Probability Sampling dan tehnik Purposive Sampling dengan populasi tidak terbatas (Roscue). Data pokok diambil melalui penyebaran kuesioner melalui media sosial WhatsApp dan diolah dengan SPSS 19.

Variabel penelitian merupakan atribut, karakter dan segala sesuatu yang terbentuk, dan yang menjadi perhatian pada penelitian, maka memiliki variasi antara satu objek lainnya pada sebuah keolompok tertentu dan selanjutnya disimpulkan. Dalam penelitian ini peneliti mengambil variabel independen (X) yaitu Brand Image, Kualitas Produk, Price dan Iklan, lalu variabel dependen (Y) adalah Minat Beli Paket Data Telkomsel, dan yang terakhir adalah variabel moderasi (Z) yaitu Di Masa Pandemi Covid 19.

\section{HASIL DAN PEMBAHASAN}

\section{Analisis Regresi Limier Berganda}

Analisis regresi linier berganda termasuk model regresi linier yang melibatkan lebih dari satu variable bebas. Analisis regresi linier berganda yaitu regresi yang mempunyai 1 variabel terikat dan 2 atau lebih variabel bebas. Terdapat analisis jalur yang digunakan peneliti untuk menganalisis, yaitu dengan menggunakan SPSS versi 19 sebagai berikut :

Tabel 1. Uji Regresi Linier Berganda dengan

Moderasi

\begin{tabular}{|c|c|c|c|c|c|}
\hline \multicolumn{6}{|c|}{ Coefficients(a) } \\
\hline \multirow[t]{2}{*}{ Model } & \multicolumn{2}{|c|}{$\begin{array}{c}\text { Unstandardized } \\
\text { Coefficients }\end{array}$} & \multirow{2}{*}{$\begin{array}{c}\text { Standardized } \\
\text { Coefficients } \\
\text { Beta }\end{array}$} & \multirow[t]{2}{*}{$\mathrm{t}$} & \multirow[t]{2}{*}{ Sig. } \\
\hline & B & $\begin{array}{l}\text { Std. } \\
\text { Error }\end{array}$ & & & \\
\hline (Constant) & $\begin{array}{c}1.48 \\
2\end{array}$ & $\begin{array}{c}1.24 \\
5\end{array}$ & & 1.190 & .238 \\
\hline $\begin{array}{l}\text { Kualitas } \\
\text { Produk }\end{array}$ & .154 & .093 & .193 & 1.666 & .101 \\
\hline $\begin{array}{l}\text { Brand } \\
\text { Image }\end{array}$ & .224 & .128 & .214 & 1.751 & .085 \\
\hline Price & .188 & .104 & .210 & 1.812 & .075 \\
\hline Iklan & .002 & .112 & .001 & .014 & .989 \\
\hline $\begin{array}{l}\text { Di Masa } \\
\text { Pandemi } \\
\text { Covid } 19\end{array}$ & .307 & .126 & .315 & 2.428 & .018 \\
\hline a. $\begin{array}{l}\text { Varia } \\
\text { Minat } \\
\text { Data }\end{array}$ & $\begin{array}{l}1 \text { Teri } \\
\text { eli Pr } \\
\text { lkom }\end{array}$ & & & & \\
\hline
\end{tabular}

Pada regresi koefisien diatas pada rumus regresi linier berganda bisa didaptkan hasil seperti berikut:

$$
\mathrm{Y}=1,482+0,154 \mathrm{X} 1+0,224 \mathrm{X} 2+0,188 \mathrm{X} 3+
$$
$0,002 \mathrm{X} 4+0,307 \mathrm{Z}$

Hasil koefisien pada regresi linier berganda tersebut, yaitu:

a. Jika $\mathrm{X} 1, \mathrm{X} 2, \mathrm{X} 3$ dan $\mathrm{X} 4$ yaitu 0 maka nilai $\mathrm{Y}=$ 1,482 . 
b. Jika variabel kualitas produk dapat ditingkatkan lebih dari 0 maka minat beli paket data telkomsel juga akan meningkat. Nilai koefisien kualiats produk adalah 0,154 .

c. Jika variabel brand image dapat ditingkatkan lebih dari 0 maka minat beli paket data telkomsel juga akan meningkat. Nilai koefisien brand image adalah 0,224 .

d. Jika variabel price dapat ditingkatkan lebih dari 0 maka minat beli paket data telkomsel juga akan meningkat. Nilai koefisien price adalah 0,188.

e. Jika variabel iklan dapat ditingkatkan lebih dari 0 maka minat beli paket data telkomsel juga akan meningkat. Nilai koefisien iklan adalah 0,002.

f. Jika variabel di masa pandemi covid 19 dapat ditingkatkan lebih dari 0 maka minat beli paket data telkomsel juga akan meningkat. Nilai koefisien di masa pandemi covid 19 adalah 0,307.

\section{Uji-f}

Tabel 2. Uji Simultan F dengan Variabel Moderasi

\begin{tabular}{llrrrrr}
\hline \multicolumn{6}{c}{ ANOVAb } \\
\hline Model & $\begin{array}{c}\text { Sum of } \\
\text { Squares }\end{array}$ & df & $\begin{array}{c}\text { Mean } \\
\text { Square }\end{array}$ & F & Sig. \\
\hline 1 & Regression & 115,331 & 5 & 23,066 & 30,876 &, 000 \\
\cline { 2 - 7 } & Residual & 47,812 & 64 &, 747 & & \\
\cline { 2 - 7 } & Total & 163,143 & 69 & & & \\
\hline
\end{tabular}

a. Predictors: (Constant), Di Masa Pandemi Covid 19, Iklan, Price, Kualitas Produk, Brand Image

b. Variabel Terikat: Minat Beli Paket Data Telkomsel

f-table : N1=K-1 = 5-1 = 4, N2 = N-K=70-5=65, f-table $=2,51$. Dari data tersebut bisa diamati bahwa seluruh variabel memiliki nilai signifikan $0.000<$ 0,005. Pada uji ini nilai f-hitung 30,876 > f-table 2,68 yang berarti bahwa hipotesis diterima dimana kualitas produk, brand image, price, iklan berpengaruh pada minat beli paket data telkomsel.

\section{Uji-t}

Tabel 3. Uji Parsial T dengan Variabel Moderasi

\begin{tabular}{|c|c|c|c|c|c|c|}
\hline \multicolumn{7}{|c|}{ Coefficients(a) } \\
\hline \multirow{2}{*}{\multicolumn{2}{|c|}{ Model }} & \multicolumn{2}{|c|}{$\begin{array}{l}\text { Unstandardized } \\
\text { Coefficients }\end{array}$} & \multirow{2}{*}{$\begin{array}{c}\text { Standardized } \\
\text { Coefficients } \\
\text { Beta }\end{array}$} & \multirow[t]{2}{*}{$\mathrm{t}$} & \multirow[t]{2}{*}{ Sig. } \\
\hline & & B & $\begin{array}{l}\text { Std. } \\
\text { Error }\end{array}$ & & & \\
\hline 1 & (Constant) & 1.482 & 1.245 & & 1.190 & .238 \\
\hline & $\begin{array}{l}\text { Kualitas } \\
\text { Produk }\end{array}$ & .154 & .093 & .193 & 1.666 & .101 \\
\hline & $\begin{array}{l}\text { Brand } \\
\text { Image }\end{array}$ & .224 & .128 & .214 & 1.751 & .085 \\
\hline & Price & .188 & .104 & .210 & 1.812 & .075 \\
\hline & Iklan & .002 & .112 & .001 & .014 & .989 \\
\hline
\end{tabular}

\begin{tabular}{|c|c|c|c|c|}
\hline $\begin{array}{l}\text { Di Masa } \\
\text { Pandemi } \\
\text { Covid } 19\end{array}$ & $.307 \quad .126$ & .315 & 2.428 & .018 \\
\hline $\begin{array}{l}\text { a. Dependent } \\
\text { Beli Paket Dat }\end{array}$ & $\begin{array}{l}\text { able: Minat } \\
\text { lkomsel }\end{array}$ & & & \\
\hline
\end{tabular}

Pembahasan dari hasil uji di atas adalah sebagai berikut, $\mathrm{Df}=70-5=65$ dan tabel $\mathrm{t}$ adalah 1,66864 dengan tarif signifikasi $t$ tabel 0,005 apabila $\alpha<0,005$ maka artinya signifikan, dikatakan berpengaruh apabila nilai pada t-hitung $>\mathrm{t}$-tabel.

1. Pada variabel Kualitas Produk (X1) di tunjukkan bahwa t-hitung $1.666>1.66864$ t-tabel dengan signifikasi $0.101>0,005$.

2. Pada variabel Brand Image (X2) di tunjukkan bahwa t-hitung $1.751>1.66864$ t-tabel dengan signifikasi $0.085>0.005$.

3. Pada variabel Price (X3) di tunjukkan bahwa thitung $1.812>1.66864$ t-tabel dengan signifikasi $0.075>0.005$.

4. Pada variabel Iklan (X4) di tunjukkan bahwa thitung $0.014>1.66864 \mathrm{t}$-tabel dengan signifikasi $0.989>0.005$.

5. Pada variabel Di Masa Pandemi Covid 19 (Z) di tunjukkan bahwa t-hitung $2.248>1.66864$ t-tabel dengan signifikasi $0.018>0.005$.

\section{Pembahasan}

Dari hasil uji data dalam penelitian di atas, maka di peroleh hasil beebrapa faktor yang memberi pengaruh pada minat beli paket data telkomsel dengan di masa pandemi covid 19 sebagai variabel moderasinya :

1. X1 tidak membawa pengaruh positif pada Minat Beli Paket Data Telkomsel (Y). Dari hasil tersebut maka H1 yang diduga Kualitas Produk (X1) memberi pengaruh signifikan pada Minat Beli Paket Data Telkomsel (Y) tidak dapat diterima dan tidak terbukti kebenarannya.

2. X2 memberi pengaruh signifikan pada Minat Beli Paket Data Telkomsel (Y). Menurut hasil tersebut maka H2 yang diduga Citra Merek (X2) membawa pengaruh positif pada Minat Beli Paket Data Telkomsel (Y) dapat diterima dan terbukti kebenarannya.

3. Variabel Price (X3) memberi pengaruh positif pada Minat Beli Paket Data Telkomsel (Y). Menurut hasil tersebut maka hipotesis ketiga (H3) yang diduga Price (X3) memberi pengaruh signifikan terhadap Minat Beli Paket Data Telkomsel dapat diterima dan terbukti kebenarannya. 
4. Variabel Iklan (X4) tidak memberi pengaruh positif pada Minat Beli Paket Data Telkomsel (Y). Dari hasil tersebut maka H4 yang diduga Iklan (X4) mempunyai pengaruh signifikan pada Minat Beli Paket Data Telkomsel (Y) tidak dapat diterima dan tidak terbukti kebenarannya.

5. Variabel Di Masa Pandemi Covid 19 (Z) memberi pengaruh positif terhadap Minat Beli Paket Data Telkomsel (Y). Dari hasil tersebut maka H5 yang diduga Di Masa Pandemi Covid 19 (Z) tidak berpengaruh signifikan terhadap Minat Beli Paket Data Telkomsel (Y) tidak dapat diterima dan tidak terbukti kebenarannya.

\section{KESIMPULAN DAN SARAN}

Kesimpulan penelitian ini yaitu di masa pandemi covid 19 ini minat beli paket data telkomsel sangat tinggi. Dapat dibuktikan dengan penyebaran kuesioner, lalu di olah uji data yang dilakukan oleh peneliti. Antusiasme masyarakat dalam pembelian paket data telkomsel juga di dukung oleh beberapa variabel yang ada seperti kualitas brand image, produk, price juga iklan. Pada variabel pertama menunjukkan bahwa kualitas produk yang baik belum tentu menjadi faktor yang mempengaruhi kepercayaan masyarakat dalam menentukan pilihan membeli paket data telkomsel maka dari itu variabel kulitas produk tidak membawa pengaruh positif pada minat beli paket data telkomsel. Di variabel yang kedua dapat kita lihat bahwa brand image juga merupakan faktor yang penting dalam kepercayaan masyarakat untuk memilih suatu produk, dimana brand image yang dimiliki telkomsel sejak dulu menjadi penentu masyarakat dalam memilih membeli paket data telkomsel maka dari itu variabel brand image memberi pengaruh positif pada minat beli paket data telkomsel. Yang ketiga yaitu variabel price atau harga dimana harga merupakan tolak ukur masyarakat dalam memilih suatu produk untuk mereka gunakan, dimana produk telkomsel menetapkan tarif harga yang sedikit lebih tinggi dari pada para pesaingnya, namun hal itu tetap tidak menurunkan minat masyarakat dalam membeli paket data telkomsel karena dengan harga yang relatif lebih mahal telkomsel juga memberi pelayanan dan kualitas di atas para pesaingnnya, maka dari itu variabel price berpengaruh signifikan terhadap minat beli paket data telkomsel. Lalu yang keempat ada variabel iklan dimana iklan yang menarik belum tentu dapat meningkatkan rasa ingin tahu konsumen terhadap suatu produk, maka dari itu variabel iklan tidak memberi pengaruh positif pada minat beli paket data telkomsel. Yang terakhir ada variabel di masa pandemi covid 19, dimana keadaan pandemi ini membuat masyarakat harus melakukan kegiatan baik bekerja ataupun sekolah dari rumah atau secara online demi meminimalisir penyebaran virus, hal itulah yang menyebabkan masyarakat harus tahu betul dalam memilih paket data untuk menunjang kegiatan mereka sehari-hari selama masa pandemi ini, maka dari itu variabel di masa pandemi covid 19 berpengaruh signifikan terhadap minat beli paket data telkomsel.

Saran dari peneliti adalah untuk peneliti selanjutnya lebih melakukan penelitian secara mendalam lagi mengeksplorasi variabel-variabel baru yang mungkin berpengaruh terhadap minat beli paket data telkomsel terutama pada masa pandemi ini yang masih belum diketahui akan berakhir kapan. Peneliti sadar bahwa penelitian yang dilakukan masih kurang sempurna dan terdapat kekurangan dalam proses penulisannya. Diharapkan penelitian ini bisa menjadi referensi serta rekomendasi kepada peneliti yang selanjutnya untuk melaksanakan penelitian lebih dalam lagi.

\section{REFERENSI}

[1] Kasinem, "Pengaruh Harga Jual dan Saluran Distribusi Terhadap Peningkatan Volume Penjualan Paket Internet Telkomsel 15 GB Pada CV . Sinar Telekom Lahat," J. Media Wahana Ekon., vol. 18, no. 1, pp. 100-109, 2021.

[2] L. Mileva and A. F. DH, "Pengaruh Social Media Marketing Terhadap Keputusan Pembelian," J. Adm. Bisnis, vol. 1, no. 1, pp. 190-199, 2018.

[3] N. Alam Hamdani and G. Abdul Fatah Maulani, "The influence of E-WOM on purchase intentions in local culinary business sector," Int. J. Eng. Technol., vol. 7, no. 2.29, p. 246, 2018, doi: 10.14419/ijet.v7i2.29.13325.

[4] I. Handaruwati, "Analisa Kualitas Pelayanan, Kepercayaan Dan Keamanan Terhadap Tindakan Pembelian Produk Secara Online," Bus. Innov. Entrep. J., vol. 2, no. 4, pp. 218 223, 2020, doi: 10.35899/biej.v2i4.165.

[5] P. Kotler and L. L. Keller, Marketing Management, 14th ed. England: Pearson Education Limited, 2013.

[6] N. A. Hamdani and G. A. F. Maulani, "The influence of E-WOM on purchase intentions in local culinary business sector," Int. J. Eng. Technol., vol. 7, no. 2.29, pp. 246-250, 2018, 
doi: 10.14419/ijet.v7i2.29.13325.

[7] G. Dash, K. Kiefer, and J. Paul, "Marketing-toMillennials: Marketing 4.0, customer satisfaction and purchase intention," J. Bus. Res., vol. 122, no. October 2020, pp. 608-620, 2021, doi: 10.1016/j.jbusres.2020.10.016.

[8] H. I. Mohammad, "7Ps Marketing Mix and Retail Bank Customer Satisfaction in Northeast Nigeria," Br. J. Mark. Stud., vol. 3, no. 3, pp. 71-88, 2015.

[9] H. R. Yuniyanto and H. Sirine, "Pengaruh Iklan terhadap Minat Beli Pengguna Youtube dengan Brand Recognition sebagai Variabel Intervening," Esensi J. Bisnis dan Manaj., vol. 8, no. 1, pp. 21-28, 2018, doi: 10.15408/ess.v8i1.5885.

[10] D. Solihin and C. Verahastuti, "Profitabilitas Sektor Telekomunikasi Di Tengah Pandemi Covid-19," Aktual J. Akunt. Dan Keuang., vol. 5, no. 2, pp. 91-98, 2020.

[11] M. Zulkarnain, "Kualitas Produk, Servicescape dan Word of Mouth Serta Pengaruhnya terhadap Keputusan Pembelian Ulang," Bus. Innov. Entrep. J., vol. 3, no. 1, pp. 38-44, 2021, doi: 10.35899/biej.v3i1.198.

[12] D. Rahayu, "Analisis Dampak Penerapan Psak 72 Terhadap Kinerja Keuangan Perusahaan Telekomunikasi Di Masa Pandemi Covid-19," Greenomika, vol. 2, no. 2, pp. 142-158, 2020, [Online]. Available: https://journal.unusida.ac.id/index.php/gnk/arti cle/view/338.

[13] P. Suchánek, J. Richter, and M. Králová, "Customer satisfaction, product quality and performance of companies," Rev. Econ. Perspect., vol. 14, no. 4, pp. 329-344, 2014, doi: 10.1515/revecp-2015-0003.

[14] A. Watson, N. K. Lecki, and M. Lebcir, "Does size matter? An exploration of the role of body size on brand image perceptions," J. Prod. Brand Manag., vol. 24, no. 3, pp. 252-262, 2015, doi: 10.1108/JPBM-05-2014-0616.

[15] F. Boronczyk and C. Breuer, "The company you keep: Brand image transfer in concurrent event sponsorship," J. Bus. Res., no. March, pp. 1-9, 2019, doi: 10.1016/j.jbusres.2019.03.022.

[16] J. L. Lee, J. D. James, and Y. K. Kim, "A Reconceptualization of Brand Image," Int. J. Bus. Adm., vol. 5, no. 4, pp. 1-11, 2014, doi: 10.5430/ijba.v5n4p1.

[17] H. Nofrianda, "ANALISIS PENGARUH KUALITAS PRODUK, KUALITAS
LAYANAN DAN HARGA TERHADAP KEPUASAN KONSUMEN (Studi Kasus Pada Konsumen Industry/ Toko Bakery di Kota Bengkulu)," Manag. Insight J. Ilm. Manaj., vol. 13, no. 1, pp. 71-85, 2019, doi: 10.33369/insight.13.1.71-85.

[18] A. Gofur, "Pengaruh Kualitas Pelayanan Dan Harga Terhadap Kepuasan Pelanggan," J. Ris. Manaj. dan Bisnis Fak. Ekon. UNIAT, vol. 4, no. 1, pp. 37-44, 2019, doi: 10.36226/jrmb.v4i1.240.

[19] A. Amron, "Effects of Product Quality, Price, and Brand Image on the Buying Decision of City Car Product," Arch. Bus. Res., vol. 6, no. 4, pp. 1-8, 2018, doi: 10.14738/abr.64.4374.

[20] A. Putra, "Pengaruh Iklan Dan Kepercayaan Merek Terhadap Minat Beli Konsumen (Studi Pada Texas Chicken Pekanbaru)," Kemamp. Koneksi Mat. (Tinjauan Terhadap Pendekatan Pembelajaran Savi), vol. 53, no. 9, pp. 16891699, 2019.

[21] E. Arista and S. Astuti, "Analisis Pengaruh Iklan, Kepercayaan Merek, dan Citra Merek terhadap Minat Beli Konsumen," J. Ilmu Ekon. ASET, vol. 13, no. 1, p. 36604, 2011, [Online]. Available:

http://journal.widyamanggala.ac.id/index.php/j urnalaset/article/view/71/45.

[22] G. S. K. Niazi, J. Siddiqui, B. A. Shah, and A. I. Hunjra, "Effective advertising and its influence on consumer buying behavior | Request PDF," Inf. Manag. Bus. Rev., vol. 4, no. 3, pp. 114-119, 2012, [Online]. Available: https://www.researchgate.net/publication/2777 54206_Effective_advertising_and_its_influenc e_on_consumer_buying_behavior.

[23] A. A. Alalwan, "Investigating the impact of social media advertising features on customer purchase intention," Int. J. Inf. Manage., vol. 42, no. June, pp. 65-77, 2018, doi: 10.1016/j.ijinfomgt.2018.06.001.

[24] J. Martins, C. Costa, T. Oliveira, R. Gonçalves, and F. Branco, "How smartphone advertising influences consumers' purchase intention," $J$. Bus. Res., vol. 94, no. August 2017, pp. 378387, 2019, doi: 10.1016/j.jbusres.2017.12.047.

[25] H. Harisno and D. Herby, "The Analysis of Factors Affecting the Buying Interest of ECommerce Customers," CommIT (Communication Inf. Technol. J., vol. 12, no. 1, p. 13, 2018, doi: 10.21512/commit.v12i1.2089.

[26] A. Spinelli and G. Pellino, "COVID-19 
pandemic: perspectives on an unfolding crisis," Br. J. Surg., vol. 107, no. 7, pp. 785-787, 2020, doi: $10.1002 /$ bjs.11627.

[27] D. M. Morens, P. Daszak, H. Markel, and J. K. Taubenberger, "Pandemic covid-19 joins history's pandemic legion," MBio, vol. 11, no. 3, pp. 1-9, 2020, doi: 10.1128/mBio.00812-20.

[28] Sugiyono, Metode Penelitian Pendidikan Pendekatan Kuantitatif, Kualitatif dan R\&D. Bandung: Alfabeta, 2006.

[29] A. G. Ramadhan and S. B. Santosa, "Analisis Pengaruh Kualitas Produk, Kualitas Pelayanan, dan Citra Merek terhadap Minat Beli Ulang pada sepatu Nike Running di Semarang melalui Kepuasan Pelanggan sebagai Variabel Intervening," Diponegoro J. Manag., vol. 6, no. 1, pp. 1-12, 2017, [Online]. Available: https://ejournal3.undip.ac.id/index.php/djom/a rticle/view/17525/16774.

[30] N. Sutrisno and A. D. Haryani, "Influence of Brand and Product Quality on Customer'S Buying Decision in South Cikarang Bekasi Regency," J. Lentera Bisnis, vol. 6, no. 1, p. 85, 2017, doi: 10.34127/jrlab.v6i1.169.

[31] N. Wijayasari and Mahfudz, "Pengaruh Brand Image, Kualitas, Persepsi Harga dan Variasi Produk Terhadap Minat Beli Konsumen Sarung Gajah Duduk di Kabupaten Pekalongan," Diponegoro J. Manag., vol. 7, no. 2, pp. 1-9, 2018, [Online]. Available: http://ejournals1.undip.ac.id/index.php/dbr.

[32] N. A. Hamdani, G. A. F. Maulani, and A. Solihat, "The Influence of Current Ratio, Debtto-equity ratio, inventory turnover, and return on investment on price-earnings ratio of cement industry companies listed at Indonesia Stock Exchange," in Advances in Business, Management and Entrepreneurship, Taylor \& Francis Group, LLC, 2020, pp. 498-504.

[33] S. Setiati and M. K. Azwar, "COVID-19 and Indonesia," Acta Med. Indones., vol. 52, no. 1, pp. 84-89, 2020. 